\author{
Anna Moskal \\ ORCID: 0000-0001-9070-069X \\ Uniwersytet Jagielloński
}

DOI: $10.19195 / 1733-5779.24 .5$

\title{
Mechanizm współpozwania w świetle przystąpienia Unii Europejskiej do Konwencji o ochronie praw człowieka i podstawowych wolności
}

\section{JEL Classification: K40 (General)}

Słowa kluczowe: mechanizm współpozwania, Unia Europejska, EKPCz

Keywords: co-respondent mechanism, European Union, EHRC

\begin{abstract}
Abstrakt: Od niemal siedemdziesięciu lat trwają dyskusje i działania nad przystąpieniem Unii Europejskiej do Europejskiej Konwencji Praw Człowieka. Ratio akcesji Unii do Konwencji stanowi konieczność harmonizacji europejskiego systemu ochrony praw jednostek, a liczne problemy i przeszkody w osiągnięciu tego celu stwarza specyficzny, ponadnarodowy charakter Unii sui generis. Wymaga on bowiem wprowadzenia specjalnych mechanizmów i procedur, które umożliwiałyby organizacji międzynarodowej zostanie stroną Konwencji. Jednym z nich jest przewidziany w art. 3 projektu porozumienia mechanizm współpozwania Unii Europejskiej i Państwa Członkowskiego w ramach postępowania toczącego się przed Europejskim Trybunałem Praw Człowieka. Celem artykułu jest przedstawienie zarzutów Trybunału Sprawiedliwości, ocena ich zasadności oraz wskazanie możliwych przyszłych rozwiązań dotyczących procedury współpozwania. Art. 3 w ustępach drugim i trzecim zapewnia Unii możliwość dołączenia do postępowania w charakterze strony współpozwanej w wypadku zarzucenia naruszenia, w ramach którego kwestionowana jest zgodność przepisu prawa wspólnotowego z Konwencją, a państwom członkowskim zostanie współpozwanymi gdy kwestionowana jest zgodność regulacji traktatowych z EKPCz. Po rozpatrzeniu wniosku Komisji Europejskiej o wydanie opinii w przedmiocie zgodności projektu porozumienia z prawem wspólnotowym Trybunał Sprawiedliwości Unii Europejskiej uznał projekt umowy za niezgodny z prawem unijnym i wypunktował dziesięć kwestii, które uniemożliwiają akcesję Unii do Konwencji w proponowanym kształcie. Trzy z nich odnoszą się do mechanizmu współpozwania i dotyczą w szczególności decydowania o zasadności wniosków Unii lub państwa członkowskiego przez Trybunał w Strasburgu, przyjęcia solidarnej odpowiedzialności przez Unię i państwa członkowskie oraz decydowania o podziale odpowiedzialności. W niniejszym artykule
\end{abstract}

* Opiekun naukowy (Scientific Tutor) — Łukasz Chyla 
autorka dokonała analizy wskazanych punktów w oparciu o metodę dogmatyczną. Ze względu na treść art. 218 par. 11 pkt 2 TFUE Komisja Europejska jest związana opinią Trybunału Sprawiedliwości Unii Europejskiej i nie może pozwolić na akcesję Unii do Konwencji w proponowanym w projekcie porozumienia kształcie.

\title{
The co-respondent mechanism in the view of accession of the European Union to the European Convention of Human Rights
}

\begin{abstract}
For the past seventy years there have been discussions and activities on the accession of the European Union to the European Convention on Human Rights. The ratio of the Union's accession to the Convention is a need to harmonize the European system of protection of individual rights. There are numerous problems and obstacles to achieve this goal created by the specific, supra-national character of the Union sui generis. It requires the introduction of unique mechanisms and procedures that would allow an international organization such as the EU to become a party to the Convention. One such procedure is provided in art. 3 of the draft agreement, the co-respondent mechanism of the European Union and the Member State in proceedings under the European Court of Human Rights. The purpose of the article is to present the allegations of the Court of Justice, assess their validity and indicate possible future solutions regarding the co-respondent mechanism. After analyzing the European Commission's request for an opinion on the compliance of the draft agreement with community law, the CJEU considered the draft as incompatible with EU law and listed ten issues that prevented the Union from joining the Convention in the proposed form. Among them, as many as three points refer to the corresponding mechanism and concern in particular the decision on the validity of the conclusions of the Union or a Member State by the Strasbourg Court, accepting joint liability and deciding on the division of responsibility between the Union and the Member State. In the article dogmatic method was used in order to analyze three aforementioned points. Due to the provision of art. 218 par. 11 p. 2 TFEU, the Commission is bound by the opinion of the Court of Justice, and that the presented draft agreement cannot constitute an international agreement allowing for the accession of the Union to the Convention in the proposed form.
\end{abstract}

\section{Wprowadzenie}

Od ponad pół wieku toczą się liczne dyskusje i debaty nad przystąpieniem Unii Europejskiej do Konwencji o ochronie praw człowieka i podstawowych wolności, nazywanej popularnie Europejską Konwencją Praw Człowieka (dalej: EKPCz, Konwencja). Chociaż już w latach pięćdziesiątych ubiegłego wieku zaczęto dostrzegać problem dualizmu systemu ochrony praw człowieka w Europie i związaną z tym potrzebę ujednolicenia go poprzez akcesję Unii do Konwencji, to dopiero w 2010 roku podjęto rzeczywiste działania zmierzające w tym kierunku. Obie zainteresowane strony, Unia Europejska i Rada Europy, wyznaczyły swoich przedstawicieli do trwających niemal trzy lata negocjacji, których efektem był pakiet pięciu instrumentów akcesyjnych. Kluczowy w tej sprawie dokument stanowi projekt porozumienia, który stał się przedmiotem wniosku Komisji Europejskiej do Trybunału Sprawiedliwości Unii Europejskiej (dalej: TSUE, Trybunał) o wydanie opinii w przedmiocie zgodności projektu porozumienia z prawem wspól- 
notowym. Dnia 18 grudnia 2014 roku Trybunał wydał przełomową opinię 2/13', w której uznał projekt umowy za niezgodny z prawem wspólnotowym. Trybunał szczegółowo przedstawił różnorodne problemy, które uniemożliwiają Unii Europejskiej przystąpienie do EKPCz w zaprezentowanej przez Komisję formie. Wśród dziesięciu postawionych przez Trybunał zarzutów względem projektu porozumienia aż trzy dotyczą mechanizmu współpozwania, który stanowi główny przedmiot analiz niniejszego artykułu.

\section{Pobudki przystąpienia Unii do Konwencji}

W dniu 3 września 1953 roku weszła w życie wielostronna umowa międzynarodowa z zakresu ochrony praw człowieka, nazwana Konwencją o ochronie praw człowieka i podstawowych wolności. Umowa ta została zawarta przez 47 państw członkowskich Rady Europy, a zatem wszyscy członkowie tej organizacji stali się jednocześnie stronami Konwencji. Początkowo ochrona praw człowieka w Europie była zapewniana jedynie w ramach Rady Europy i systemu opartego na EKPCz, w szczególności na orzecznictwie działającego na podstawie art. 19 EKPCz Europejskiego Trybunału Praw Człowieka (dalej: ETPCz, Trybunał w Strasburgu). Wspólnotom Europejskim natomiast przyświecał cel integracji i współpracy głównie na podłożu ekonomicznym. $Z$ czasem jednak dostrzeżono, iż integracja gospodarcza może stwarzać realne zagrożenie dla ochrony praw człowieka. W 1952 roku, na mocy Traktatu Paryskiego z 1951 roku, ustanowiono Europejski Trybunał Sprawiedliwości (obecnie Trybunał Sprawiedliwości Unii Europejskiej). Trybunałowi przyznano określone w traktatach uprawnienia do orzekania, które wykonuje najczęściej w ramach procedury odesłania prejudycjalnego i postępowań w przedmiocie wyliczonych skarg. Przez kilkadziesiąt lat swojej działalności Trybunał odegrał niebagatelną rolę w rozwoju koncepcji praw człowieka we Wspólnotach.

Równoległe interpretowanie przepisów prawa europejskiego zarówno przez TSUE, jak i Trybunał w Strasburgu doprowadziło do dualizmu europejskiego systemu ochrony praw człowieka. Warte odnotowania jest, iż obecnie podmioty prawa wspólnotowego nie mogą kierować skarg na akty organów Unii Europejskiej bezpośrednio do Europejskiego Trybunału Praw Człowieka, ponieważ Unia nie jest stroną Konwencji. Dostrzegalna jest tendencja do coraz częstszego wnoszenia skarg do Trybunału w Strasburgu przeciwko państwom członkowskim w związku z aktami wydanymi przez organy i instytucje unijne ${ }^{2}$. Wskazane byłoby za-

1 Opinia Trybunału Sprawiedliwości 2/13 z 18 grudnia 2014 roku w sprawie przystąpienia Unii Europejskiej do europejskiej Konwencji o Ochronie Praw Człowieka i Podstawowych Wolności, EU:C:2014:2454, http://curia.europa.eu/juris/document/document.jsf?docid=160882\&doclang=PL (dostęp: 15.09.2018).

2 J. Barcz, A. Wyrozumska, M. Górka, Instytucje i prawo Unii Europejskiej: podręcznik dla kierunków prawa, zarządzania i administracji, wyd. 5, Warszawa 2017, s. 341. 
tem wprowadzenie do prawa wspólnotowego zasad ochrony praw człowieka, aby umożliwić instytucjom Unii uczestniczenie i obronę własnych racji przed ETPCz. Takie rozwiązanie byłoby korzystne również dla państw członkowskich, które niejednokrotnie odpowiadały za naruszenia praw człowieka poprzez implementację do porządku krajowego przepisów prawa Unii, do których stosowania państwa członkowskie są zobligowane. Jednostki bowiem, nie mogąc złożyć skargi bezpośredniej na akt unijny, wnoszą liczne skargi pośrednie na regulacje krajowe, które dany akt implementują. Akcesja Unii do Konwencji miałaby również duży impakt polityczny — akty wydane przez jej instytucje i organy zostałyby poddane kontroli zewnętrznej, a UE wykazałaby, że nie „stoi ponad prawem”3.

Słusznie podnosi się w literaturze przedmiotu, że przystąpienie Unii Europejskiej do EKPCz stanowi obecnie najpoważniejsze i najtrudniejsze wyzwanie polityczne oraz instytucjonalne dla całego systemu ochrony praw człowieka w Europie ${ }^{4}$. Z uwagi na wyjątkowy charakter sui generis Unii Europejskiej jako organizacji międzynarodowej, która dysponuje szerokimi uprawnieniami i kompetencjami oraz ponadnarodowy charakter, jej akcesja do Konwencji niewątpliwie jest skomplikowanym procesem wymagającym głębokiej analizy i drobiazgowych negocjacji.

\section{Historia działań podjętych w celu akcesji Unii Europejskiej do Konwencji}

Idea akcesji Unii do Konwencji pojawiła się po raz pierwszy na początku lat pięćdziesiątych XX wieku w projekcie Traktatu Wspólnot Europejskich (Politycznych), który ostatecznie nie wszedł w życie ${ }^{5}$. W 1979 roku Komisja Europejska w swoim memorandium ${ }^{6}$ złożyła propozycję przystąpienia Wspólnot Europejskich do Konwencji, argumentując, iż takie działanie będzie zapewniało najskuteczniejszą ochronę praw człowieka. Pomimo że opinia Komisji została podzielona przez Parlament Europejski najpierw w 1982, a później w 1989 i 1990 roku, nie podejmowano żadnych realnych działań zmierzających w tym kierunku. W 1990 roku Komisja Europejska ponowiła swój wniosek, prosząc Radę Unii Europejskiej

3 Ibidem, s. 343.

4 Takprzykładowo A. Gajda,Przystapienie Unii EuropejskiejdoEuropejskiej Konwencjioochronie praw człowieka i podstawowych wolności, Kwartalnik Kolegium Ekonomiczno-Społecznego „Studia i Prace” 2013, nr 1, s. 11; B. Wścisły-Białek, Proces negocjacyjny porozumienia dotyczacego przystapienia Unii Europejskiej do Europejskiej Konwencji Praw Człowieka, „Europejski Przegląd Sądowy" grudzień 2015, s. 8.

5 G. de Burca, The Road Not Taken: the European Union as a Global Human Rights Actor, New York 2011, s. 649.

${ }^{6}$ Memorandum Komisji z dnia 2 maja 1979 roku, Memorandum on the accession of the Communities to the European Convention on Human Rights, COM (79) 210 final, przyjęte przez Komisję 4 kwietnia 1979 roku. 
o zgodę na akcesję Wspólnoty do EKPCz oraz o upoważnienie do rozpoczęcia negocjacji zgodnie z zaproponowanymi wytycznymi.

Dnia 26 kwietnia 1994 roku Rada UE zdecydowała się uzyskać opinię Trybunału Sprawiedliwości w sprawie ewentualnego przystąpienia Unii do EKPCz na podstawie art. 300 ust. 6 Traktatu ustanawiającego Wspólnotę Europejską (dalej: TWE). W opinii Trybunału Sprawiedliwości 2/947 z dnia 28 marca 1996 roku TSUE stwierdził, że w obowiązującym ówcześnie stanie prawa wspólnotowego Wspólnota Europejska nie miała kompetencji do przystąpienia do Konwencji. Owo przystąpienie doprowadziłoby, zdaniem Trybunału, do zasadniczej modyfikacji istniejącego unijnego modelu ochrony praw człowieka poprzez umieszczenie Wspólnoty w odrębnym, międzynarodowym systemie instytucjonalnym i wprowadzenie wszystkich postanowień EKPCz do wspólnotowego porządku prawnego. Trybunał stwierdził, iż takiej modyfikacji można byłoby dokonać jedynie za pomocą zmiany traktatów, a wówczas traktaty nie zawierały podstawy prawnej, która przewidywałaby możliwość przystąpienia UE do EKPCz.

Wymagany przepis kompetencyjny pojawił się po raz pierwszy w Traktacie ustanawiającym Konstytucję dla Europy, jednakże akt ten nie został ratyfikowany. Przepis ów przeniesiono zatem do Traktatu z Lizbony ${ }^{8}$, który nadał nowe brzmienie art. 6 TUE. Obecnie art. 6 ust. 2 TUE stanowi wprost, że „Unia przystępuje do europejskiej Konwencji o ochronie praw człowieka i podstawowych wolności. Przystąpienie do konwencji nie narusza kompetencji Unii określonych w Traktatach". Zagadnieniu temu poświęcono także Protokół nr 8 dotyczący artykułu 6 ust. 2 TUE w sprawie przystąpienia Unii do Europejskiej Konwencji o ochronie praw człowieka i podstawowych wolności, dołączony do Traktatu z Lizbony, oraz Deklarację nr 2, która stanowi, iż przystąpienie Unii Europejskiej do EKPCz powinno nastąpić w taki sposób, aby można było zachować szczególny charakter porządku prawa wspólnotowego.

Stanowisko Rady Europy niezmiennie od rezolucji Zgromadzenia Parlamentarnego z $1981 \mathrm{roku}^{9}$ wspierało ideę przyłączenia Unii do Konwencji. W celu umożliwienia akcesji Unii dokonano zmian w samej Konwencji. Dnia 13 maja 2004 roku przyjęto Protokół nr 14, który wprowadził ustęp 2 do art. 59 EKPCz. Przepis ten stanowi, że „Unia Europejska może przystąpić do niniejszej Konwencji”. Protokół nr 14 wszedł w życie w czerwcu 2010 roku i umożliwił dalsze działania

7 Opinia Trybunału Sprawiedliwości 2/94 z dnia 28 marca 1996 roku, Przystąpienie Wspólnoty do Konwencji o ochronie praw człowieka i podstawowych wolności, http://curia.europa.eu/juris/ document/document.jsf?text=\&docid=99549\&pageIndex=0\&doclang=PL\&mode=1st\&dir=\&occ $=$ first\&part=1\&cid=23440 (dostęp: 15.09 .2018$)$.

8 Traktat z Lizbony zmieniający Traktat o Unii Europejskiej i Traktat ustanawiający Wspólnotę Europejską, sporządzony w Lizbonie dnia 13 grudnia 2007 roku, Dz.U. z 2009 r. Nr 203, poz. 1569.

9 Rezolucja Zgromadzenia Parlamentarnego rady Europy z 1981 roku, Resolution on the accession of the European Communities to the European Communities to the European Convention on Human Rights, 4649. 
zmierzające do akcesji Unii Europejskiej do Konwencji. W szczególności Komitet Ministrów Rady Europy w maju 2010 roku upoważnił Komitet Sterujący do spraw Praw Człowieka Rady Europy do rozpoczęcia procesu wypracowywania wspólnego stanowiska ze stroną unijną, obejmującego warunki akcesji Unii do EKPCz.

W dniu 17 marca 2010 roku Rada Unii Europejskiej przyjęła decyzję upoważniającą do podjęcia negocjacji dotyczących porozumienia w sprawie przystąpienia i wyznaczała Komisję jako negocjatora. W lipcu 2010 roku rozpoczęto oficjalne negocjacje między wybranymi ekspertami z Unii Europejskiej i Rady Europy z negocjatorem Unii - Komisją Europejską. Owocem pierwszych ośmiu spotkań grupy negocjacyjnej był projekt instrumentów akcesyjnych, który złożono do akceptacji Komitetowi Sterującemu do spraw Praw Człowieka Rady Europy. Niestety projekt odrzucono ze względu na istotne obiekcje co do treści umowy, a Unia zaczęła w praktyce blokować proces akcesji ${ }^{10}$. Negocjacje wznowiono dopiero w drugiej połowie 2012 roku po decyzji Rady Unii Europejskiej ds. Wymiaru Sprawiedliwości i Spraw Wewnętrznych o potrzebie pilnego wznowienia negocjacji i akceptacji kompromisowej propozycji mandatu Komisji do dalszych negocjacji. Dnia 21 czerwca 2012 roku odbyła się pierwsza runda rozmów, w formule 47 przedstawicieli państw członkowskich Rady Europy +1 (negocjator UE - Komisja Europejska). Grupa negocjacyjna 47+1 odbyła łącznie pięć spotkań. Dnia 5 kwietnia 2013 roku po rocznych negocjacjach przyjęto ostateczny pakiet pięciu instrumentów akcesyjnych, które tworzą:

1) projekt porozumienia dotyczącego przystąpienia Unii Europejskiej do $\mathrm{EKPCz}{ }^{11}$;

2) deklaracja Unii Europejskiej składana w momencie podpisania porozumienia;

3) reguła, która ma zostać dodana do Regulaminu Komitetu Ministrów Rady Europy w odniesieniu względem nadzoru nad wykonywaniem wyroków i warunków polubownego rozwiązywania sporów w wypadkach, w których UE jest stroną;

4) modelowe memorandum of understanding pomiędzy UE a państwem trzecim niebędącym członkiem Unii Europejskiej;

5) raport wyjaśniający do porozumienia dotyczącego przystąpienia.

10 Tak B. Wścisły-Białek, op. cit., s. 10, z odniesieniem do: N. Nielson, UK obstructing EU accession to human rights convention, „EUobserver” 2012, http://euobserver.com/justice/115954 (dostęp: 15.09.2018).

11 Fifth Negotiation Meeting between the CDDH ad hoc negotiation group and the European Commission on the Accession of the European Union to the European Convention on Human Rights, Final Report to the CDDH, 10 czerwca 2013 roku, 47+1(2013) 008rev2, http:// www.coe. int/t/dghl/standardsetting/hrpolicy/accession/Meeting_reports/47_1(2013)008rev2_EN.pdf. (dostęp: 15.09.2018). 


\section{Mechanizm współpozwania w projekcie porozumienia}

Wynegocjowany projekt porozumienia zawiera krótką preambułę i dwanaście artykułów. Jak słusznie wskazał Trybunał w opinii $2 / 13$, przepisy zawarte w projekcie porozumienia dotyczącego przystąpienia Unii Europejskiej do Konwencji można podzielić na dwie kategorie - pierwsza obejmuje regulacje dotyczące przystąpienia $\mathrm{w}$ ścisłym znaczeniu tego słowa i wprowadza mechanizmy proceduralne konieczne do zapewnienia skutecznej akcesji Unii do EKPCz, natomiast postanowienia drugiej mają charakter czysto techniczny, związany głównie z koniecznością dostosowania terminologii Konwencji do specyficznego ponadpaństwowego charakteru Unii jako strony Konwencji.

Artykuł 1 ust. 3 projektu porozumienia określa zakres zobowiązań Unii po jej przystąpieniu do Konwencji. Zgodnie z tym przepisem Unia poniesie zobowiązania $\mathrm{w}$ odniesieniu do aktów, środków lub zaniechań jej organów i instytucji oraz w stosunku do osób działających w jej imieniu. Natomiast żaden przepis Konwencji lub Protokołu nie może nakładać na Unię zobowiązania do podjęcia działania lub przyjęcia środka, które przekraczałyby umocowanie wynikające $\mathrm{z}$ prawa unijnego. $Z$ kolei ust. 4 analizowanego artykułu zawiera tzw. klauzulę przypisywalności, której celem jest zapewnienie kierowania skarg do prawidłowego adresata - odpowiednio albo do Unii Europejskiej, albo do państwa członkowskiego. Przepis ten wiąże się z mechanizmem współpozwania przewidzianym w art. 3 projektu porozumienia, który ma go wprowadzić do art. 36 ust. 4 EKPCz.

W ustępach drugim i trzecim art. 3 projektu porozumienia przewidziany jest mechanizm współpozwania, który umożliwia Unii Europejskiej włączenie się w postępowanie w charakterze strony współpozwanej. Taką możliwość przewiduje się w sytuacji gdy kwestionowana jest zgodność przepisu prawa unijnego z Konwencją. Analogicznie państwa członkowskie mogą zostać współpozwanymi, gdy kwestią sporną jest problem zgodności przepisów traktatowych z EKPCz. Stroną współpozwaną można zostać albo na skutek zaproszenia Trybunału w Strasburgu, albo jego decyzji wydanej po dokonaniu oceny, czy w świetle argumentów przedstawionych przez układającą się stronę wiarygodne jest, że przesłanki naruszeń $\mathrm{z}$ ust. 2 i 3 art. 2 zostały spełnione. Ustęp 6 art. 3 projektu porozumienia stanowi, iż w przypadku, w którym Trybunał nie zbadał jeszcze zgodności przepisu prawa unijnego z rozpatrywanymi prawami określonymi w Konwencji lub protokołach, do których Unia przystąpiła, TSUE przyznaje się czas konieczny na przeprowadzenie takiego badania. Mechanizm ten jest nazywany procedurą wcześniejszego zaangażowania Trybunału.

Po akceptacji projektu Komisja Europejska, na podstawie art. 218 ust. 11 TFUE, zwróciła się do Trybunału Sprawiedliwości z wnioskiem o wydanie opinii w przedmiocie zgodności projektu porozumienia z prawem wspólnotowym. Dnia 18 grudnia 2014 roku Trybunał wydał przełomową opinię 2/13, która do 
dziś uznawana jest za kamień milowy w orzecznictwie TSUE. W opinii Trybunał uznał projekt umowy za niezgodny z prawem unijnym. Opinia $2 / 13$ zawiera spis różnorodnych problemów, które uniemożliwiają Unii Europejskiej przystąpienie do EKPCz w zaprezentowanym przez Komisję kształcie. W konsekwencji konieczne są dalsze prace nad projektem porozumienia, a wiele ze wskazanych przez Trybunał przeszkód poddano krytyce - wymagają one dogłębnej analizy, w tym w szczególności opisany już mechanizm współpozwania.

\section{Mechanizm współpozwania w opinii 2/13}

Trybunał Sprawiedliwości Unii Europejskiej wydał opinię 2/13 w sprawie projektu porozumienia dotyczącego przystąpienia Unii do EKPCz po ponad 17 miesiącach od jego złożenia przez Komisję. Opinia ta została wydana w pełnym składzie 28 sędziów po wysłuchaniu opinii niemieckiej Rzecznik Generalnej Juliany Kokott oraz zapoznaniu się Trybunału z pisemnymi uwagami 24 rządów państw członkowskich, Komisji Europejskiej, Parlamentu Europejskiego i Rady Unii Europejskiej. Pomimo wyrażenia pozytywnych opinii przez wszystkie wskazane instytucje TSUE uznał projekt porozumienia za niezgodny z art. 6 ust. 2 TUE oraz Protokołem nr 8. Jak słusznie zauważył Andrzej Wróbel, obiekcje Trybunału można pogrupować w formie 10 zarzutów $^{12}$. Jak już wspomniano we wstępie artykułu, aż trzy ze wskazanych zarzutów odnoszą się do mechanizmu współpozwania, a dotyczą w szczególności decydowania o zasadności wniosków Unii lub państwa członkowskiego przez Trybunał w Strasburgu, przyjęcia solidarnej odpowiedzialności przez Unię i państwa członkowskie oraz decydowania o podziale odpowiedzialności.

\section{a) kwestia decydowania o wnioskach Unii lub państwa członkowskiego w ramach mechanizmu współpozwania}

Mechanizm współpozwania został zaprojektowany jako najbardziej praktyczne rozwiązanie problemu ustalenia podziału kompetencji między UE a państwami członkowskimi, tak aby rozpatrywany wniosek był kierowany do strony faktycznie odpowiedzialnej za domniemane naruszenie. Zgodnie z art. 3 ust. 5 projektu porozumienia Unia lub państwo członkowskie mogą stać się stroną przypozwaną po przyjęciu zaproszenia od Trybunału w Strasburgu albo w drodze decyzji ETPCz podjętej na wniosek układającej się strony. O ile Trybunał Sprawiedliwości uznaje tę pierwszą możliwość, o tyle drugi sposób budzi poważne zarzuty. W wypadku gdy Unia lub państwo członkowskie złoży wniosek o dopuszczenie w charakterze współpozwanego, Trybunał w Strasburgu miałby podjąć decyzję

12 A. Wróbel, Dekalog akcesyjny, czyli dziesięć argumentów Trybunału Sprawiedliwości przeciwko Unii Europejskiej do Europejskiej Konwencji Praw Człowieka, „Europejski Przegląd Sądowy" grudzień 2015, s. 4. 
po dokonaniu kontroli wiarygodności przedstawionych przez wnioskodawcę argumentów. W ramach tej kontroli mogłoby dojść do badania przepisów prawa unijnego, które regulują rozdział kompetencji między Unią a państwami członkowskimi oraz kryteriów przypisywalności ich aktów i zaniechań. Zdaniem Trybunału taka kontrola nie miałaby charakteru automatycznego i mogłaby kolidować z rozdziałem kompetencji między Unię a państwa członkowskie.

Do zbliżonego (chociaż odmiennie uzasadnionego) wniosku doszła w swojej opinii Rzecznik Generalna, uznając, że art. 3 ust. 5 projektu porozumienia wyposaża ETPCz w dyskrecjonalne uprawnienie dopuszczania wniosków współpozwanych w oparciu o wiarygodność przytaczanych przez nich argumentów. W przeciwieństwie do Trybunału J. Kokott dostrzega w takiej procedurze nie tyle uchybienie w stosunku do zasady rozdziału kompetencji między Unią a państwami członkowskimi, ile istotne zagrożenie dla art. 1 lit. b) Protokołu nr 8 UE, którego celem jest zapewnienie skutecznej obrony prawa Unii przed ETPCz. W przypadku gdy Trybunał w Strasburgu nie uzna argumentacji wniosku za wiarygodną, Unia lub inne państwa członkowskie będą pozbawione udziału w postępowaniu przed ETPCz, nawet gdyby podmioty te uważały, iż konieczna jest w tym postępowaniu obrona prawa unijnego. Jak podkreśla Rzecznik Generalna, taka sytuacja godziłaby w zasadę autonomii prawa Unii, która w samym swoim założeniu zakłada przyjęcie odpowiedzialności Unii bądź państwa członkowskiego bez udziału pozaunijnego czynnika zewnętrznego.

W konsekwencji zarówno Trybunał Sprawiedliwości, jak i Rzecznik Generalna uznają przewidziane w projekcie porozumienia uprawnienie ETPCz do dokonywania kontroli wiarygodności uzasadnień wniosków za niedopuszczalne. Problem ten będzie z pewnością wymagał dalszych negocjacji stron i w ocenie autorki artykułu pozostanie jedną z najżarliwiej dysputowanych kwestii.

\section{b) kwestia przyjęcia solidarnej odpowiedzialności w ramach mechanizmu współpozwania}

Kolejną podniesioną przez Trybunał kwestią w ramach mechanizmu współpozwania jest przyjęcie w art. 3 ust. 7 projektu porozumienia odpowiedzialności solidarnej państwa członkowskiego i Unii za naruszenie postanowienia EKPCz, wobec którego dane państwo członkowskie zgłosiło zastrzeżenie na podstawie art. 57 Konwencji. Przepis ten umożliwia każdej stronie Konwencji dokonanie zastrzeżenia podczas podpisywania Konwencji lub składania dokumentów ratyfikacyjnych. Zastrzeżenia można dokonać jedynie w takim zakresie, w jakim ustawa obowiązująca na jego terytorium jest $\mathrm{z}$ tym przepisem niezgodna.

W ocenie Trybunału Sprawiedliwości przyjęcie w takim przypadku solidarnej odpowiedzialności Unii Europejskiej i państwa członkowskiego jest niezgodne $\mathrm{z}$ art. 2 Protokołu nr 8 UE, zgodnie $\mathrm{z}$ którym porozumienie w sprawie przystąpienia Unii do Konwencji ma gwarantować, że żadne z jej postanowień nie będzie 
miało wpływu na szczególną sytuację państw członkowskich w odniesieniu do Konwencji, a w szczególności do składanych do niej zastrzeżeń.

Zdaniem autorki artykułu w rzeczywistości problem ten wydaje się wydumany i tylko teoretyczny. Wątpliwe, by w praktyce ETPCz decydował o odpowiedzialności solidarnej albo wysyłał zaproszenie do stania się stroną przypozwaną do państwa członkowskiego, które złożyło zastrzeżenie do przepisu, który naruszyła Unia — takie zachowanie byłoby irracjonalne i nieuzasadnione. $Z$ tego względu uważam, że zarzut Trybunału jest chybiony. Ponadto kwestia ta nie została poruszona w pismach rządów państw członkowskich ani w opinii Rzecznik Generalnej J. Kokott, co zdaje się potwierdzać hipotetyczny charakter wskazanego przez Trybunał zagrożenia. Gdyby strony chciały zastosować się do opinii Trybunału, należałoby dodać przepis, który wykluczałby możliwość pociągnięcia do odpowiedzialności solidarnej państwa członkowskiego, które złożyło zastrzeżenia do normy, którą naruszyła Unia.

\section{c) kwestia decydowania o podziale odpowiedzialności między Unię i państwo członkowskie w ramach mechanizmu współpozwania}

Art. 3 ust. 7 in fine projektu porozumienia przewiduje wyjątek od zasady solidarnej odpowiedzialności pozwanego i współpozwanego z tytułu aktu lub zaniechania stanowiącego naruszenie przepisów Konwencji. Zgodnie z tym przepisem Trybunał w Strasburgu, po wysłuchaniu argumentów przedstawionych przez pozwanego i współpozwanego oraz po wysłuchaniu stanowiska skarżącego ETPCz, może postanowić, że do odpowiedzialności za to naruszenie należy pociągnąć tylko jednego z nich. Decyzja ETPCz opiera się między innymi na ocenie przepisów prawa unijnego, regulujących rozdział kompetencji między Unię a państwa członkowskie. Pomimo iż Trybunał w Strasburgu ma orzekać wyłącznie w oparciu o przedstawioną argumentację, zdaniem TSUE takie rozwiązanie narusza rozdział kompetencji między Unią a jej państwami członkowskimi. Ponadto, Trybunał Sprawiedliwości słusznie zwraca uwagę, że projekt porozumienia nie przewiduje explicite, aby pozwany i współpozwany musieli wspólnie przedstawić spójną argumentację. Można jednak polemizować z konkluzją TSUE, iż „kwestia odpowiedzialności powinna zostać rozstrzygnięta wyłącznie na podstawie właściwych przepisów prawa Unii i w razie potrzeby poddana kontroli Trybunału, który ma wyłączną właściwość w zakresie zapewnienia, że porozumienie między współpozwanym i pozwanym respektuje te przepisy".

Oczywiste jest, że celem Trybunału Sprawiedliwości jest utrzymanie monopolu jurysdykcyjnego na interpretację prawa unijnego po przystąpieniu Unii do Konwencji. Jak jednak słusznie zauważa Krystyna Kowalik-Bańczyk, przyjęcie wyłączności Unii Europejskiej na wykładnię Konwencji jest niemożliwe, a należy się liczyć z sytuacją, w której ocena Trybunału w Strasburgu co do zgodności rozwiązania unijnego z Konwencją będzie wiązać się z interpretacją prawa 
Unii $^{13}$. Pomimo iż po akcesji Unii do Konwencji EKPCz stałaby się immanentną częścią prawa unijnego, wyłączność jurysdykcyjna Trybunału Sprawiedliwości nie rozciągnie się przecież na całą treść Konwencji i wskazane byłoby zatem uznanie przez TSUE pewnych ustępstw względem Trybunału w Strasburgu. Takim ustępstwem mogłoby być właśnie niepodważanie kompetencji ETPCz do wydawania decyzji o podziale odpowiedzialności za naruszenie Konwencji między państwami członkowskimi a Unią, szczególnie że projekt porozumienia przewiduje podjęcie decyzji w oparciu o przedstawioną argumentację stron.

W konsekwencji istnieją dwie możliwości dalszego działania w tym zakresie - albo zaakceptowanie obecnego rozwiązania pomimo negatywnego stanowiska TSUE w tej kwestii, albo wyłączenie możliwości decydowania przez ETPCz o podziale odpowiedzialności między Unią a państwami członkowskimi w wypadku, gdy wymagane jest interpretowanie przepisów unijnych (w takiej sytuacji ETPCz powinno się zwrócić z prośbą o dokonanie wykładni do TSUE). Na drugie ze wskazanych rozwiązań Rada Europy prawdopodobnie nie wyrazi zgody. W ocenie autorki artykułu wyłączną kognicję w tym zakresie powinien mieć Trybunał w Strasburgu.

\section{Konkluzje}

Przepis art. 218 ust. $11 \mathrm{zd} .2$ TFUE, stanowiący podstawę prawną wniosku Komisji Europejskiej o wydanie opinii w przedmiocie zgodności projektu porozumienia z prawem wspólnotowym, przesądza, iż „w przypadku negatywnej opinii Trybunału przewidywana umowa nie może wejść w życie, chyba że nastąpi jej zmiana lub rewizja Traktatów". Oznacza to, iż Komisja jest związana opinią Trybunału Sprawiedliwości, a przedstawiony projekt porozumienia nie może w zaproponowanym kształcie stanowić umowy międzynarodowej pozwalającej na akcesję Unii do Konwencji, o której mowa w art. $216 \S 1$ TFUE. Konieczne zatem będzie takie zmodyfikowanie mechanizmu współpozwania, które z jednej strony wypełniałoby swoją rolę, a z drugiej satysfakcjonowało Trybunał. Mechanizm współpozwania jest niezbędny do zapewnienia prawidłowego podziału odpowiedzialności między UE a państwami członkowskimi, tak aby rozpatrywany przez ETPCz wniosek był kierowany do strony faktycznie odpowiedzialnej za domniemane naruszenie. Nie tylko ma on zapewniać odpowiedni rozdział odpowiedzialności między UE a państwami członkowskimi, lecz także musi respektować autonomiczny system prawny Unii. W związku z tym, aby móc utrzymać procedurę przypozwania, ale jednocześnie uszanować zdanie Trybunału Sprawiedliwości, konieczne będzie dokonanie rewizji ustępów 5, 6 i 7 w art. 3 projektu porozumienia.

13 K. Kowalczyk-Bańczyk, Autonomia prawa unijnego w świetle opinii 2/13, „Europejski Przegląd Sądowy” grudzień 2015, s. 18. 


\section{Bibliografia}

Barcz J., Wyrozumska A., Górka M., Instytucje i prawo Unii Europejskiej: podręcznik dla kierunków prawa, zarzadzania i administracji, wyd. 5, Wolters Kluwer Polska, Warszawa 2017.

Burca de G., The Road Not Taken: the European Union as a Global Human Rights Actor, New York 2011.

Gajda A., Przystapienie Unii Europejskiej do Europejskiej Konwencji o ochronie praw człowieka i podstawowych wolności, Kwartalnik Kolegium Ekonomiczno-Społecznego „Studia i Prace” 2013, nr 1.

Kowalczyk-Bańczyk K., Autonomia prawa unijnego w świetle opinii 2/13, „Europejski Przegląd Sądowy” grudzień 2015.

Wróbel A., Dekalog akcesyjny, czyli dziesięć argumentów Trybunału Sprawiedliwości przeciwko Unii Europejskiej do Europejskiej Konwencji Praw Człowieka, „Europejski Przegląd Sądowy” grudzień 2015.

Wścisły-Białek B., Proces negocjacyjny porozumienia dotyczacego przystapienia Unii Europejskiej do Europejskiej Konwencji Praw Człowieka, „Europejski Przegląd Sądowy” grudzień 2015.

\section{Akty prawne}

Fifth Negotiation Meeting between the CDDH ad hoc negotiation group and the European Commission on the Accession of the European Union to the European Convention on Human Rights, Final Report to the CDDH, 10 czerwca 2013 r., 47+1(2013) 008rev2.

Memorandum Komisji z dnia 2 maja 1979 roku, Memorandum on the accession of the Communities to the European Convention on Human Rights, COM (79) 210 final, przyjęte przez Komisję 4 kwietnia 1979 roku.

Opinia Trybunału Sprawiedliwości 2/94 z dnia 28 marca 1996 roku, Przystąpienie Wspólnoty do Konwencji o ochronie praw człowieka i podstawowych wolności.

Opinia Trybunału Sprawiedliwości 2/13 z 18 grudnia 2014 roku w sprawie przystąpienia Unii Europejskiej do europejskiej Konwencji o Ochronie Praw Człowieka i Podstawowych Wolności, EU:C:2014:2454.

Rezolucja Zgromadzenia Parlamentarnego rady Europy z 1981 roku, Resolution on the accession of the European Communities to the European Communities to the European Convention on Human Rights, 4649.

Traktat z Lizbony zmieniający Traktat o Unii Europejskiej i Traktat ustanawiający Wspólnotę Europejską, sporządzony w Lizbonie dnia 13 grudnia 2007 roku, Dz.U. z 2009 r. Nr 203, poz. 1569.

\section{The co-respondent mechanism in the view of accession of the European Union to the European Convention of Human Rights}

\section{Summary}

The provision of art. 218 par. 11 p. 2 TFEU, the legal basis for the European Commission's request for an opinion on the compliance of the draft agreement with community law, states that "in the event of a negative opinion of the Court, the envisaged agreement may not enter into force unless it is amended or revisited." This means that the Commission is bound by the opinion of the Court of Justice, and that the presented draft agreement cannot constitute an international agreement allowing for the accession of the Union to the Convention in the proposed form. It is necessary to modify the corresponding mechanism, which, on one hand, has to fulfill its role, and on the other, has to satisfy the Tribunal. The corresponding mechanism is necessary to ensure a proper 
division of responsibility between the EU and the Member States. Not only does it ensure an adequate distribution of responsibility, but it also has to respect the autonomous legal system of the Union. Therefore, in order to be able to keep the co-respondent mechanism procedure, but at the same time respect the Court of Justice's opinion, it will be necessary to revise paragraphs 5,6 and 7 in art. 3 of the draft agreement. 